\title{
THE USE OF SCAFFOLDING STRATEGY IN TEACHING READING COMPREHENSION AT THE FIRST GRADE STUDENTSOF SMA N 4 MATARAM IN ACADEMIC YEAR2017/2018
}

\author{
Patmah Siswanti ${ }^{1}$ Hidayati $^{2}$, Rima Rahmaniah ${ }^{3}$ \\ ${ }^{1}$ Pendidikan Bahasa Inggris, Universitas Muhammadiyah Mataram, patmasiswanti@gmail.com
}

\section{INFO ARTIKEL}

Riwayat Artikel:

Diterima: 03-02-2018

Disetujui: 12-03-2018

\section{Kata Kunci: \\ ScaffoldingStrategy \\ Reading Comprehension}

\begin{abstract}
ABSTRAK
Abstract: Scaffolding is a teaching learning strategy in which the teacher and learners engage in a collaborative problem-solving activity with the support and guidance of the teacher to enable learners become increasingly independent. Scaffolding strategy can help students solved the task by their own and student can be understand the material. The purpose of this research is to know whether the use of scaffolding strategy is effective or not in teaching reading comprehension at the first grade students of SMA N 4 Mataram in academic year of 2017/2018. This study used Quasi Experimental Non-Equivalent Control Group Designs, the researcher was used pre-test and post-test. The sample of this research were all students of the first grade at SMAN 4 Mataram that consist of 78 students, 39 students of experimental group and 39 students of control group. The experimental group was taught by scaffolding strategy in teaching reading comprehension and the control group was taught without scaffolding strategy in teaching reading comprehension. The techniques of collecting data in this research used pre-test and post-test. Based on the result, the means score of students experimental group was 23,17 and the control group was 16,70. It was shows that score of experimental group was higher than control group. Whereas, the score of t-test was 2,70 and the score of t-table was 2,00 on the level of significance 0,05 . this research shows that scaffolding strategy in teaching reading comprehension at the first grade students of SMAN 4 Mataram in Academic Year 2017/2018 is effective. So, based on the hypothesis that the researcher discussed before, the Alternative Hypothesis $(\mathrm{Ha})$ was accepted.
\end{abstract}

\section{A. INTRODUCTION}

Reading is one of important skills in learning English , reading skills as a far of receptive skills is given the first priority in the language curriculum. It involves students interacting with visual input of language, which they need to process and understand. Ability in reading will help the students to comprehend the texts. By reading, they make sense what the writer means. They can also catch the information in the texts even the detail information of each paragraph. This has to be supported by other components, such as: vocabularies, structures, and many others to understand their meaning that can be a model to improve students' knowledge (Pollard,2008:44).

Reading has very important role in learning process because the skill of reading determine the success of students in learning many things particularly in daily life. For those reasons teacher should try to make reading interesting, enjoyable, and meaningful. In fact, there are often some phenomenon in the schools, in which many teachers who less an attention toward student in teaching to comprehending the text. It could be seen when the researcher conducted her teaching practice (PPL) in SMAN 4 Mataram. The teachers who less an attention toward students in teaching to comprehending the text. The teacher just give the text and ask student to repeat the teacher's reading without some preparation before so it make students difficult to understand the text what was conveyed in the reading text that was read by the teacher. In this condition the teacher did not build students' background knowledge what the reading text initially that make they often missed the information of the texts.Teaching reading to English learners is exciting for Teacher who Have the ability to perform it. They have skill and competence to apply the appropriate teaching strategies and teaching method which can motivate the student to enjoy the printing material they distribute.

Based on the condition above, the researcher is interesting to conduct the research to the first grade students of SMA N 4 Mataram. Furthermore, the Researcher try to solve and improve the students' reading comprehension. From many choices of strategies in improving reading comprehension, the researcher choose scaffolding technique as an alternative strategy to help the students in reading comprehension in order to make students become active, enjoy, and comprehend. Bruner (1978 : 56) describes 'scaffolding' as cognitive support given by teachers to learners and help them to solve tasks that they would not be able working on their own. Students go on to describe this as a form of "vicarious consciousness" in which students are taken beyond themselves through participation in the consciousness of the teacher.

As with any teaching technique, scaffolds should complement instructional objectives. While we expect all of our students to grasp course content, each of them will not have the necessary knowledge or capability to initially perform as we have intended. Scaffolds can be used to 
support students when they begin to work on objectives that are more complex or difficult to complete.

There are some relevant previous studies that support this research. First, Ni putu eva yanti (2014) " Improving Reading Comprehension hrough Scaffolding Reading Experience Strategy of the eighth Grade Student of SMPN 1 Kuta Utara In Academic year 2013/2014. Showed that there was positive responses concerning the strategy applied in improving the subjects' reading comprehension. To sum up, the present classroom action study proved that SRE strategy could improve reading comprehension of the eighth grade students of SMPN 1 Kuta Utara in academic year 2013/2014. Moreover, the subjects also responded positively the implementation of SRE strategy.

Second, Rosmawar Tanjung “ Improving Students' Seading Comprehension of Narrative Text through Scaffolding Strategy at Grade X of SMAN 1 TUKKA, TANAPULI TENGAH, PADANG " showed that almost all of students were interested to scaffolding strategy and most students could understand the test easier.

Considering those reasons, the researcher uses this strategy in teaching reading comprehension. Furthermore, the researcher is very interested in conducting the research entitled "The use of scaffolding in teaching reading comprehension at the first grade students of SMA N 4 Mataram in Academic Year 2017/2018".

\section{Purpose of The Study}

The specific purposes of the study based on research question as followed to knew whether the use of scaffolding strategy is effective or not in teaching reading comprehension at the first grade students of SMA N 4 Mataram in academic year of 2017/2018

\section{Significant of The Study}

The result of this study is intended to gave contribution in teaching English both theoretically and practically.

1. Theoretically

a. As a teaching technique reference in teaching learning process

b. As a reference to the other researcher who wants study scaffolding more intensively in teaching reading comprehension.

2. Practically

a. The result of this study is expected to help the teachers to solve the problems in teaching and learning of reading comprehension

b. Make students are more enjoyable to comprehend reading text.

\section{Scope and Limitation of The Study}

In order to investigated more deeply, the researcher limited on the subject and object of the study.

1. The participant of this study is limited to the first grade student SMAN 4 Mataram in academic year of $2017 / 2018$

2. The object reading descriptive text about people, place, animals and thing. (Bahasa Inggris : buku guru / Kementerian Pendidikan dan Kebudayaan. -Jakarta: Kementerian Pendidikan dan Kebudayaan, 2014. Untuk SMA/SMK kelas X dan www.sekolahbahasainggris.com).
3. The use of Scaffolding strategy scema building in teaching reading comprehension

\section{B. RESEARCH METHOD}

This chapter covers research method that used in this study, there were research design, population and sample, instrument, the method of data collecting, and the techniques of data analysis.

\section{Research Design}

This research design of this study was Quasi Experimental Design where there was no randomization between control group and experimental group or called as nonequivalent control group design because the researcher cannot manipulated all of the student as sample (Sugiono, 2013:166). In addition, this method was the most appropriate method to knew effective or not the use of scaffolding in teaching reading comprehension. Therefore, the data from the pre-test and post test calculation to investigate the use of scaffolding application in this research.

\section{Population and Sample}

\section{a. Population}

The population in this study was the first grade students of SMA N 4 Mataram in academic year 2017/2018. Arikunto (2013:173) says that population is the whole subject of a research. Furthermore, the researcher states that Population was the total number of the subjects of an investigation. The population in this research was the whole student of X SMA N 4 Mataram which consists of 312 student they were science class 156 students and social class 156 students.

\section{b. Sample}

Arikunto (2013:174) states that sample is a smaller part of the population that taken as an object of a research. In this study, the researcher used cluster random sampling. Cluster rondom sampling is sampling which is used to determine if the object of the sample of the source of data is very wide so the researcher only took the sample based on the area population which has determined (Sugiyono (2016: 121). In SMA N 4 Mataram there were 8 classes at first grade which consist of 4 IPA class and 4 IPS class. The researcherl took 2 IPS class, especially in X IPS 2 and X IPS 1. X IPS 2 (39 students) as experiment group and X IPS 1 (39 students) as control group so the total sample number was 78 students.

\section{Research Instrument}

In this research, the researcher used a test as an instrument of collect the data. Test is a set of questions that are used for measuring the ability, knowledge, talent or skill of individual or a group (Arikunto, 2013:30). An instrument was important element to find out the result of research, so the researcher had to prepare the instrument well. The form of the test is objective test which was Consist of 25 questions descriptive text about people, place, animal and thing (Bahasa Inggris : buku guru / Kementerian Pendidikan dan Kebudayaan. -- Jakarta: Kementerian Pendidikan dan Kebudayaan, 2014. Untuk SMA/SMK kelas X dan www.sekolahbahasainggris.com). Each question gave 
4 scores, so the total of the score becomes 100 (Hundred).

\section{The Data Collecting Method}

In this research used a test as an instrument of collect the data, and the data was collected by giving a pre-test and a post-test to the experimental group.

\section{a. Pre-test}

At the first meeting the researcher gave the students set of reading test which aimed to know the students' initial proficiency in adding before the treatment gave. The result of the test count for the data compare with the result of the post-test. The students were given reading comprehension test in multiple choices item which consist of 25 questions descriptive text about people, place, animal, and thing. This test aimed in the testing the students reading comprehension.

\section{b. Treatment}

In this step the researcher provided the different treatment to the two classes. In experimental class the researcher utilized "scaffolding" as medium in teaching reading comprehension and In control class the researcher without involving scaffolding as the medium in teaching reading comprehension. Hopefully these two different treatments would be able to make difference in student's ability in reading comprehension.

\section{c. Post-test}

The next procedure is post-test this test being conducted after pre-test and treatment is given to the student. The result of the test counted for the data. In this research the researcher given post test questions in multiple choices item which consist of 25 questions descriptive text about people, place, animal, and thing. Finally the result of this test showed us student capability after the different treatment given. The classification of student score was as the following table:

TABLE 1

TABLE OF READING SCORE

\begin{tabular}{|c|l|c|c|}
\hline No & Qualification & Degree & Qualitative \\
\hline 1 & Excellent & $80-100$ & A \\
\hline 2 & Good & $70-79$ & B \\
\hline 3 & Fail & $60-69$ & C \\
\hline 4 & Poor & $50-59$ & D \\
\hline 5 & Complete poor & $0-49$ & E \\
\hline
\end{tabular}

(Hatch and Farhady, 1982;82)

Table above means:

$$
\text { (Hatch }
$$

1. Excellent (4)

Those students who were able to answer the test items between 80-100 correctly

2. Good (3)

Those students who were able to answer the test items between 70-79 correctly

3. Fail (2)

Those students who were able to answer the test items between 60-69 correctly

4. Poor (1)

Those students who were able to answer the test items between 50-59 correctly

5. Complete poor
Those students who were able to answer the test items between 0-50 correctly

Then the researcher analyzed the students result to find out their ability through their reading test result.

\section{The Data Analysis Method}

In this part, to obtain the students' score both groups, the researcher will process the score with the following steps:

1. The researcher calculated the means scores of both experimental and control group

2. The researcher drew standard deviation scores of two groups.

3. The researcher testing the significance of two deviations.

a. Mean score of experimental group:

$$
\boldsymbol{M} \boldsymbol{X}=\frac{\sum X}{N}
$$

$$
\text { And }
$$

Mean score of control group

$$
\boldsymbol{M} Y=\frac{\sum Y}{N}
$$

Where:

M: The mean score of the two groups

$\mathrm{X}$ : The students' final score foR experimental group

Y: The students' final score for control group

$\mathrm{N}$ : Is the number of sample

$\sum$ : Is the sum of......

b. Finding the standard deviation of two groups. The formula as To Find out the standard deviation of experimental group.

The formula is:

$$
\sum x^{2}=\sum x^{2}-\frac{(X)^{2}}{N x}
$$

$\sum \mathrm{x}^{2} \quad$ : The standard deviation for experimental group

$\mathrm{N} \quad$ : The number of sample

$\mathrm{Nx}$ : The sample of the experimental group

Find out the standard deviation of control group The formula is:

Where

$$
\sum \mathrm{y}^{2}=\sum \mathrm{y}^{2}-\frac{(\mathrm{y})^{2}}{\mathrm{Ny}}
$$

$\sum y^{2} \quad$ : The standard deviation for control group

$\mathrm{N} \quad$ : The number for sample

Ny : : The sample of the control group

The last, in the testing the hypothesis of this research, the research will use the t-test.

$$
\mathrm{T}=\frac{M X-M Y}{\sqrt{\left\lfloor\frac{1}{N x}+\frac{1}{N y} \mid \frac{\sum x^{2}+\sum Y^{2}}{(N x+N y)-2}\right.}}
$$

Where:

Mx: Mean score of control group

My: Mean score of experimental group

$\mathrm{N}$ : Total numbers of the subject

$\mathrm{x}$ : The deviation of control group

$y$ : The deviation of experimental group

a) If $t$-test $<\mathrm{t}$-table in the significance of $0,05(\mathrm{p}=0,01)$, Ho is rejected. It means that the experimental groups have higher skill in speaking than control groups.

b) If t-test $>\mathrm{t}$-table in the significance level of 0,05 $(p=0,01)$, Ho is accepted. It means that the control 
groups have lower skill in speaking than experimental groups. (Arikunto, 2010: 354)

\section{DISCUSSION AND DATA INTERPRETATION}

In this chapter, the researcher would like to present the description of the data obtained. The population of this study was the first students of SMAN 4 Mataram in academic year $2017 / 2018$. The sample was chosen by using cluster sampling techniques, so the sample in this study was divided into two classes, they are X IPS 2 and X IPS 1. X IPS 2 as the experimental group ( 39 students) and X IPS 1 as the control group (39 students), the total number of the sample was 78 students.

\section{Computation of Means Score}

The students' individual scores both experimental and control groups can be seen on the following tables. They has description briefly based on the student achievement in pre-test and post-test.

TABLE 2

THE DEVIATION SCORE OF EXPERIMENTAL GROUP

\begin{tabular}{|c|l|c|c|c|c|}
\hline \multirow{2}{*}{ NO } & \multirow{2}{*}{ RESPONDENT } & \multicolumn{4}{|c|}{ Final Score } \\
\cline { 3 - 6 } & & $\mathrm{X} 1$ & $\mathrm{X} 2$ & $\begin{array}{c}\text { X } 1 \\
\text { X2- }\end{array}$ & $\mathrm{X}^{2}$ \\
\hline 1 & AFA & 48 & 72 & 24 & 576 \\
\hline 2 & AF & 52 & 72 & 20 & 400 \\
\hline 3 & AR & 56 & 84 & 28 & 784 \\
\hline 4 & ADH & 48 & 64 & 16 & 256 \\
\hline 5 & AFA & 60 & 92 & 32 & 1024 \\
\hline 6 & DA & 68 & 92 & 24 & 576 \\
\hline 7 & FNC & 56 & 80 & 24 & 576 \\
\hline 8 & IGH & 52 & 72 & 20 & 400 \\
\hline 9 & IGAAS & 72 & 84 & 12 & 144 \\
\hline 10 & IWP & 52 & 100 & 48 & 2304 \\
\hline 11 & IWS & 44 & 72 & 28 & 784 \\
\hline 12 & IWPN & 44 & 68 & 24 & 576 \\
\hline 13 & IBMED & 68 & 92 & 24 & 576 \\
\hline 14 & II & 72 & 100 & 28 & 784 \\
\hline 15 & KAS & 56 & 84 & 28 & 784 \\
\hline 16 & KI & 56 & 80 & 24 & 576 \\
\hline 17 & KYDP & 72 & 96 & 24 & 576 \\
\hline 18 & MAPW & 68 & 88 & 20 & 400 \\
\hline 19 & NKAU & 72 & 76 & 4 & 16 \\
\hline 20 & NKS & 40 & 68 & 28 & 784 \\
\hline 21 & NLASU & 76 & 76 & 0 & 0 \\
\hline 22 & NLPAA & 52 & 92 & 40 & 1600 \\
\hline 23 & NMAS & 76 & 100 & 24 & 576 \\
\hline 24 & NMDS & 72 & 96 & 24 & 576 \\
\hline 25 & NTD & 56 & 88 & 32 & 1024 \\
\hline 26 & NY & 56 & 92 & 36 & 1296 \\
\hline 27 & NPU & NSA & 42 & 28 & 784 \\
\hline 29 & RSD & RSS & 28 & 784 \\
\hline 30 & & 48 & 784 \\
\hline 28 & & & 576 \\
\hline
\end{tabular}

\begin{tabular}{|c|c|c|c|c|c|}
\hline 31 & RFZ & 72 & 88 & 16 & 256 \\
\hline 32 & RA & 36 & 64 & 28 & 784 \\
\hline 33 & SM & 52 & 68 & 16 & 256 \\
\hline 34 & $\mathrm{TU}$ & 44 & 68 & 24 & 576 \\
\hline 35 & $\mathrm{AQ}$ & 68 & 88 & 20 & 400 \\
\hline 36 & IPAS & 52 & 60 & 8 & 64 \\
\hline 37 & IM & 56 & 72 & 16 & 256 \\
\hline 38 & RA & 68 & 80 & 12 & 144 \\
\hline 39 & WI & 60 & 80 & 20 & 400 \\
\hline \multicolumn{4}{|c|}{$\Sigma$} & 904 & 24032 \\
\hline
\end{tabular}

TABLE 3

THE DEVIATION SCORE OF CONTROL GROUP

\begin{tabular}{|l|l|c|c|c|c|}
\hline \multirow{2}{*}{ NO } & \multirow{2}{*}{ RESPONDENT } & \multicolumn{4}{|c|}{ Final Score } \\
\cline { 3 - 6 } & & Y1 & Y2 & $\begin{array}{c}\text { Y=Y2- } \\
\text { Y1 }\end{array}$ & $\mathrm{Y}^{2}$ \\
\hline 1 & \multirow{2}{*}{ ARR } & 48 & 80 & 32 & 1024 \\
\hline 2 & AUAF & 52 & 80 & 28 & 784 \\
\hline 3 & AS & 68 & 60 & -8 & 64 \\
\hline 4 & DNU & 52 & 72 & 20 & 400 \\
\hline 5 & DNTW & 76 & 92 & 16 & 256 \\
\hline 6 & DSG & 36 & 72 & 36 & 1296 \\
\hline 7 & DAF & 64 & 64 & 0 & 0 \\
\hline 8 & DH & 52 & 72 & 20 & 400 \\
\hline 9 & DNP & 64 & 80 & 16 & 256 \\
\hline 10 & DAA & 60 & 68 & 8 & 64 \\
\hline 11 & FA & 52 & 68 & 16 & 256 \\
\hline 12 & FR & 60 & 88 & 28 & 784 \\
\hline 13 & FH & 40 & 80 & 40 & 1600 \\
\hline 14 & HF & 64 & 80 & 16 & 256 \\
\hline 15 & IGAAN & 60 & 60 & 0 & 0 \\
\hline 16 & IKAP & 40 & 72 & 32 & 1024 \\
\hline 17 & INAAR & 52 & 80 & 28 & 784 \\
\hline 18 & INA & 64 & 72 & 8 & 64 \\
\hline 19 & IWD & 52 & 76 & 24 & 576 \\
\hline 20 & IAMP & 28 & 40 & 12 & 144 \\
\hline 21 & \multirow{2}{*}{ JE } & 44 & 80 & 36 & 1296 \\
\hline 22 & LIH & 64 & 64 & 0 & 0 \\
\hline 23 & LPN & 52 & 68 & 16 & 256 \\
\hline 24 & MMS & 68 & 76 & 8 & 64 \\
\hline 25 & MSH & 68 & 64 & -4 & 16 \\
\hline 26 & MD & 40 & 72 & 32 & 1024 \\
\hline 27 & NLKS & 48 & 56 & 8 & 64 \\
\hline 28 & NWAO & 52 & 64 & 12 & 144 \\
\hline 29 & NWJ & 56 & 56 & 0 & 0 \\
\hline 30 & NSK & 76 & 80 & 4 & 16 \\
\hline 31 & RP & 52 & 84 & 32 & 1024 \\
\hline 32 & UN & 44 & 56 & 12 & 144 \\
\hline 33 & BR & 44 & 28 & 784 \\
\hline
\end{tabular}




\begin{tabular}{|c|l|c|c|c|c|}
34 & DKR & 76 & 92 & 16 & 256 \\
\hline 35 & IGWD & 52 & 76 & 24 & 576 \\
\hline 36 & IGMRS & 40 & 48 & 8 & 64 \\
\hline 37 & INBNW & 40 & 60 & 20 & 400 \\
\hline 38 & NMSA & 80 & 92 & 12 & 144 \\
\hline 39 & NNT & 28 & 44 & 16 & 256 \\
\hline \multicolumn{5}{|c}{$\Sigma$} & \\
\hline
\end{tabular}

After getting the score of deviation of pre-test and post-test, the main score of two groups can be computed it can be formulated as follos:

a. Mean score of experimental group:

$$
\begin{aligned}
\boldsymbol{M} \boldsymbol{X} & =\frac{\Sigma \mathrm{X}}{N} \\
& =\frac{904}{39} \\
& =23,17
\end{aligned}
$$

And

b. Mean score of control group

$$
\begin{aligned}
M Y & =\frac{\sum Y}{N} \\
& =\frac{652}{39} \\
& =16,7
\end{aligned}
$$

\section{Computation of Standard Deviation}

As explained above, the mean score of each group is obtained by dividing the sum of deviation score with the number of sample in the groups, here is the evaluation

a. Standard deviation of experimental group

$$
\begin{aligned}
\sum x^{2} & =\sum x^{2}-\frac{(X)^{2}}{N x} \\
= & 24.032-\frac{(904)^{2}}{39} \\
= & 24.032-\frac{817.216}{39} \\
= & 24.032-20.954 \\
= & 3.078
\end{aligned}
$$

b. Standard deviation of control group

$$
\begin{aligned}
& \sum y^{2}=\sum y^{2}-\frac{(y)^{2}}{N X} \\
& =16.560-\frac{(652)^{2}}{39} \\
& =16.560-\frac{425.104}{39} \\
& =16.560-10.900,10 \\
& =5.660
\end{aligned}
$$

\section{Computation of t-test}

The process of determining whether the experimental treatment is significance or not ,can be seen from the result of following formula.

$$
\begin{aligned}
\text { t-test } & =\frac{M X-M Y}{\sqrt{\left\lfloor\frac{1}{N x}+\frac{1}{N y} \mid \frac{\sum x^{2}+\sum Y^{2}}{(N x+N y)-2}\right.}} \\
& =\frac{23,17-16,7}{\sqrt{\left[\frac{1}{39}+\frac{1}{39} \mid \frac{3078+5660}{(39+39)-2}\right.}} \\
= & \frac{6,47}{\sqrt{[0,025+0,025] \frac{8738}{76}}} \\
= & \frac{6.47}{\sqrt{[0,05] 114,97}} \\
= & \frac{6.47}{\sqrt{5,74}}
\end{aligned}
$$

$$
\begin{aligned}
& =\frac{6.47}{2,39} \\
& =2,70
\end{aligned}
$$

The analysis of the data in this research is aimed to find the deviation mean score, $t$-test score was 2,70 . Now, it is to be interpreted to find out if it is significant or not. Before the researcher check the table of distribution, the researcher has to define the degree of freedom (df) first by using this formula $\mathrm{df}=$ $(\mathrm{Nx}+\mathrm{Ny})-2 \cdot(39+39)-2=76$.

Finally, comparing the result of t-test at the degrees of freedom (df) for 76 at the competence

\begin{tabular}{|c|c|c|c|c|c|c|}
\hline \multirow[b]{2}{*}{ No } & \multirow{2}{*}{$\begin{array}{c}\text { Classificatio } \\
\mathbf{n}\end{array}$} & \multirow{2}{*}{ Score } & \multicolumn{2}{|c|}{ Frequency } & \multicolumn{2}{|c|}{ Percentage } \\
\hline & & & $\begin{array}{l}\text { Pre- } \\
\text { test }\end{array}$ & $\begin{array}{l}\text { Post- } \\
\text { test }\end{array}$ & $\begin{array}{l}\text { Pre- } \\
\text { test }\end{array}$ & $\begin{array}{l}\text { Post- } \\
\text { test }\end{array}$ \\
\hline 1 & Excellent & $\begin{array}{c}80 \text { to } \\
100 \\
\end{array}$ & 0 & 21 & $0 \%$ & $54 \%$ \\
\hline 2 & Good & 70 to 79 & 8 & 9 & $\begin{array}{c}20,5 \\
\%\end{array}$ & $23 \%$ \\
\hline 3 & Fail & 60 to 69 & 7 & 9 & $18 \%$ & $23 \%$ \\
\hline 4 & Poor & 50 to59 & 15 & 0 & $\begin{array}{c}38,5 \\
\%\end{array}$ & $0 \%$ \\
\hline 5 & $\begin{array}{l}\text { Complete } \\
\text { Poor }\end{array}$ & 0 to 49 & 9 & 0 & $23 \%$ & $0 \%$ \\
\hline \multicolumn{3}{|c|}{ Total } & 39 & 39 & $100 \%$ & $\begin{array}{c}100 \\
\%\end{array}$ \\
\hline
\end{tabular}
interval of 0,05 was 2,00 and 0,01 was 2,65, the comparison was done between t-test formula with $\mathrm{t}$ table in which the result of t-test was 2,70 moreover the study indicates the degree of difference between two of mean score for both of the groups were significant enough at the two confidence levels. The critical value of $t$-table on the level of significance 0,05 was 2,00 and 0,01 was 2,65 it was found that $\mathrm{t}$ test was higher than $t$-table $(2,70>2,00>2,65)$. So, Alternative Hypothesis (Ha) In The Use Of Scaffolding Strategy In Teaching Reading Comprehension At The First Student Of SMAN 4 Mataram In Academic Year 2017/2018 was accepted.

\section{The Classification of the Students' Score Experiment Group}

Here is the table of rate percentage gained by Experimental group before and after given Treatment on test which is shown by table as follows:

\section{TABLE 4}

THE RATE PERCENTAGE OF THE STUDENTS' SCORE EXPERIMENTAL GROUP BEFORE AND AFTER THE TREATMENT

Based on the table above shows that before and after the treatment given, the firstly, before the treatment given, most of the students were in "Excellent" with percentage $0 \%$, some of the students were in "Good" with percentage 20,5\%, students were in "Fail" with percentage $18 \%$, students were in "Poor" with percentage 38,5\%, and students were in "Complete poor" with percentage $23 \%$. Lastly, after the treatment given, most of students were in "Excellent" with percentage $54 \%$, some of the students were in "Good" with percentage $23 \%$, some of the students were in "Fail" with percentage $23 \%$ also, students were in "Poor" with percentage $0 \%$, and students were in "Complete Poor" with percentage $0 \%$. 
The researcher has done in the research, it was applied Scaffolding Strategy in Teaching Reading Comprehension at the first grade students of SMAN 4 Mataram in class X IPS, they are class X IPS 2 (Experimental group) and X IPS 1 (Control group). Based on the data collecting method that was explained above, this research was divided into three steps. Firstly, the researcher gave pre-test to the student to know the ability of the students' before they get treatment by using scaffolding strategy. Secondly, the researcher gave the student treatment by using scaffolding strategy, after they were taught by using scaffolding strategy, they were can understood the material and also can solved the task by their own. Last, the researcher gave them post-test after they got treatment.

The student's reading comprehension skill after they were taught by using scaffolding strategy is better than before being taught using scaffolding strategy. It showed by the t-test was higher than ttable $(2,70>2,00>2,65)$. It means that there is significant scores at the first grade students of SMAN 4 Mataram before using scaffolding strategy and after using scaffolding strategy.

Based on the result of analysis of the deviation score of pre-test and post-test, continued the calculation the computation of the means scores, then we can see which group obtained the better scores after the treatment. For the experimental group the mean scores is 23,17 and for the control group is 16,70 , it show that the score of experimental group was higher than control group.

To check the significant was effective or not of the treatment, the researcher analyzed by using t-test formula. The result of the t-test was 2,70. Then, the researcher checked the critical value on the t-table of significant level $0,05 \%$ was 2,00 and $0,01 \%$ was 2,65 . From the result, it was found that t-test was higher than t-table $(2,70>2,00>2,65)$. It means that there was significant was effective of using scaffolding strategy in teaching reading comprehension.

Teaching reading comprehension using scaffolding strategy makes student can be understand the material and can solved the task by their own, it is because scaffolding strategy can be used to support student when they begin to work on objectives that are more complex or difficult to complete and student could minimize the level of frustration in doing the task. Scaffolding is a teaching learning strategy in which the teacher and learners engage in a collaborative problem-solving activity with the support and guidance of the teacher to enable learners become increasingly independent (Richards and Schmidt, 2002:466).

Based on the result above, the researcher concludes that used scaffolding strategy in teaching reading comprehension is effective and Alternative Hypothesis (Ha) which states that the Use of Scaffolding Strategy in Teaching Reading Comprehension at The First Students of SMAN 4 Mataram In Academic Year 2017/2018 was accepted.

\section{CONCLUSION AND SUGGESTION}

\section{CONCLUSION}

Based on the research finding above, the use of scaffolding in teaching reading comprehension at the first grade students of SMAN 4 Mataram in academic year $2017 / 2018$ is effective. It was proved by the obtained score of $\mathrm{t}$-test. The $\mathrm{t}$-test showed that $\mathrm{t}$-test 2,70 was higher than t-table 2,00.There was a significant difference in the achievement between $\mathrm{X}$ IPS 2 (experimental group) who were taught using scaffolding strategy and X IPS 1 (control group) who were taught without scaffolding strategy. the mean score of experimental group was 23,17 than the mean score of control group was 16,70 . It means that experimental group was better than control group. \%). From this fact, it was clear that mean score of both groups has a difference. It means the alternative hypothesis (Ha) was definitely accepted. the researcher concludes that used scaffolding strategy in teaching reading comprehension is effective.

\section{SUGGESTION}

Based on the study above, the researcher gives some suggestion for the teacher, students and researcher:

a. English teacher is a motivator and stimulation. The teacher should support the students' expectation about reading and arouse their interest to increase their reading comprehension, the teacher should control the student's activities

b. The student should keep motivation and practice their English everyday and everywhere, in order they will get better achievement in learning English, the student are expected can practice about reading comprehension $\mathrm{n}$ student also hoped to study seriously.

c. The other researcher is expected to give and confirm other finding in same area of this research as contribution to the difficulties and problems faced by the students in teaching and learning English especially in reading comprehension.

d. The last, this result is expected to be the additional reference at university of muhammadiyah mataram.

\section{ACKNOWLEDGEMENT}

Praise be to Allah the Almighty for all his bounties and blessings and for enabling the writer to accomplished this thesis. In finishing this thesis, the writer has received many valuable and meaningful contributions, suggestions, and guidance from others. Therefore, the writer is indebled to many people for their efforts and I would like to extend my sincere gratitude to: Mrs. Hidayati, M.Hum, the head of English Department Program, and also the first Consultant who has educated supported, directed, and given the writer advice, suggestion, and recommendation for this graduating thesis from beginning until the end.Mrs. Rima Rahmaniah, M.pd, the second consultant who has educated supported, directed, and given the writer advice, suggestion, and recommendation for this graduating thesis from beginning until the end. 


\section{REFERENCES}

[1] Alderson , J. Charles.(2000). Assessing Reading. Cambridge : Cambridge University Press.

[2] Arikunto, suharsimi. (2010). Procedur penelitian pendekatan praktik.Jakarta : rinekacipta

[3] Brown, D. H. (2001). Teaching by Principles: An Interactive Approach to Language Pedagogy. White Plains: Pearson Education Company.

[4] Brown, H. D. (2000). Principles of Language Learning and Teaching (Fourth Edition) New York: Pearson Education.

[5] Bruner, J. (1978). Actual Minds, Possible Worlds. Cambridge: Harvard University

[6] Cooper, J.D. (2000). Literacy: Helping Children Construct Meaning (4th ed.). Boston: Houghton Mifflin.

[7] Gibbons, P . (2002). Scaffolding language, scaffolding learning. Pourtsmouth: Heinemann

[8] Harmer, J. (1998). How to Teach English. Essex: Pearson Education Limited.

[9] Hatch, E \& Farhady, H. (1982). Research Design and Statistics for Applied Linguistics. Massachusetts: Newbury House Publishers Inc

[10] Isnaini, yulia. (2014). Using Scaffolding Technique to Improve the Writing Ability of the Second Grade of SMAN 5 Mataram.Malang: State University of Malang (Un Publish)

[11] Klingner, J.K; Vaughn, S; Boardman, A. (2007). Teaching Reading Comprehension with Learning Difficulties. Newyork: The Guilford Press.

[12] Lenz,keith. (2005). An Introduction ti Reading Comprehension. Retrieved on August 10 th, 2010 at http ://www.specialconnections.ku.edu

[13] Mahmoud . (2015). Effectiveness of Using Scaffolding Strategy on Developing Seventh Grader's Reading Comprehension Skills. Gaza : The Islamic University of Gaza

[14] McKenzie, (2011). The Impact of a Scaffolding Strategy on Elementary English Language Leaner's' Reading Performance. Unpublished doctoral dissertation. Minnesota, Walden University.

[15] McKenzie, Jamie, (1999). Scaffolding for Success. From Now On: The Educational Journal, Vol. 9, No. 4. Retrieved November 1, 2002, from http://www.fno.org/dec99/scaffold.html.

[16] Pang, S. et al. (2003). Teaching Reading. Brussels: International Academy of Education (IAE).

[17] Pang. Elizabeth S. (2003). Teaching Reading. The International Academy of Education (IAE), The International Bureau of Education (IBE) : Brussels, Belgium.

[18] Pollard, L. (2008). Luccy pollard's Guide to Teaching English Press.

[19] Richards, Jack C. and Richard Schmidt.(2002).Longman Dictionary of Language Teaching and Applied Linguistics.3rd ed. London: Pearson Education Limited.

[20] Smith, F. (2004). Understanding Reading: A Psycholinguistic Analysis of Reading and Learning to Read. Lawrence Erlbaum Associate. New Jersey London.

[21] Snow, C., Chair. (2002). Reading for Understanding (Towards an R\&D Program in Reading Comprehension). Santa Monica: RAND.
[22] Sugiyono, (2013). Metode penelitian pendidikan. Bandung : Alfabeta

[23] Sugiyono, (2016). Metode penelitian pendidikan. Bandung : Alfabeta

[24] Tanjung, Rosmawar. Improving student's Reading Comprehension of Narrative Text Through Scaffolding Strategy at The Second Grade of SMAN 1 Tukka. Padang : State University of Padang

[25] Yanti, Ni Putu Eva. (2014). Improving Reading Comprehension Through Scaffolding Reading Experience Strategy of The Eight Grade Student of SMPN 1 Kuta Utara In Academic Year 2013/2014. Denpasar : Mahasaraswati Denpasar university

\section{THE WRITER PROFIL}

The writers name is Patmah Siswanti. Was born on BREBES, 4 March 1994. Elementary school was began from SDN 5 Banjar-Anyar BREBES on year 2003-2008. After that, was continued at SMPN 3 BREBES on year 2008-2010 and the last at SMKN 1 MATARAM on year 2010-2012 in

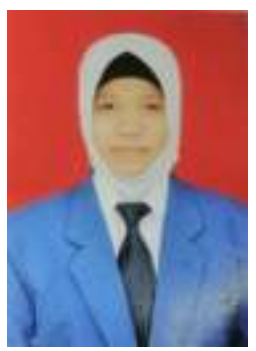
Accounting Program. Then the writer was continued at University of Muhammmadiyah Mataram in English education program FKIP UM Mataram on 2013. Suggestion and critics or the improvement of this research that has connection with my journal you can be sent it via e-mail in : patmasiswanti10@gmail.com 